Vol. 5, No. 1, 2019

Vasyl Brytkovskyi ${ }^{1}$, Roman Kachmar ${ }^{2}$, Olena Lanets ${ }^{3}$

1. Department of Operation and Repair of Automotive Vehicles, Lviv Polytechnic National University, Ukraine, Lviv, S. Bandery street 12, E-mail: vasyl.m.brytkovskyi@1pnu.ua

2. Department of Operation and Repair of Automotive Vehicles, Lviv Polytechnic National University, Ukraine, Lviv, S. Bandery street 12, E-mail: katchmar@i.ua 3. Department of Technical Mechanics and Dynamics of Machines, Lviv Polytechnic National University, Ukraine, Lviv, S. Bandery street 12,E-mail: lanecolena@gmail.com

\title{
INFLUENCE OF THE IGNITION SYSTEM PARAMETERS ON THE ECOLOGICAL INDICATORS OF THE AUTOMOBILE GAS-FUELED ENGINE
}

Received: April 03, 2019 / Revised: June 08, 2019 / Accepted: June 26, 2019

(C) Brytkovskyi V., Kachmar R., Lanets O., 2019

\begin{abstract}
The structure of the automobile service, since the beginning of the independence of Ukraine, has changed acutely. The number of private vehicles, the quality of service of which depends on the owner only, has increased. In addition to already existing automobile transport enterprises which has at least some existing production facilities with available cars of post-Soviet production and Russian cars of the middle time of Ukraine's independence, a large number of private small motor vehicles companies without any production base have appeared (in the best occasion with the available storage area), technical condition of the movable composition of which does not meet the requirements of European countries and the main transporting direction of these enterprises was concentrated in the directions of post-Soviet countries.

In order to maximize efficiency, the owners of such vehicles carry out the transformation of power supplies to the system supplied with gas fuel. Despite the sufficient number of advantages, such refurbishment requires the introduction of constructive modifications and adjustments also in the ignition system of motor vehicles. And here, in the absence of systematic state control, many of the car owners in pursuit of maximum economy, trying not to make changes, causing violations in the work of car systems, which leads not only to the growth of fuel consumption and reducing of the effective performance of the engine, but also to increasing of emission of toxic components with the exhaust gas flow of the car engines. In conditions of Ukrainian cities, where emissions of toxic components by transport sources are up to $90 \%$ of all harmful effects [11], the search for ways to improve the system of technical service of vehicles is relevant in order to control and reduce the level of environmental hazards from the operation of vehicles. Therefore, researches that focus on determining the influence of regulation of the ignition system of engines powered by gas fuel, on the example of the spark plug gap influence on the indicators of the content of the components of the exhaust gases, are relevant.

The method of research on the influence of the spark plug gap on the change in the composition of exhaust gases was developed in the paper, the research was carried out on ZAZ Lanos 1.4 engine MeMZ 317, on which is an assembly of gas equipment of the 4th generation Stag 200 GoFast. All experiments were carried out on the equipment of the Training Center for Computer Diagnostics of Vehicles "Lviv Polytechnic - Bosch Academy". A set of new Champion RN9YC spark plugs was used, the gap of which was changed from 0.6 to $1.4 \mathrm{~mm}$ with a pitch of $0.1 \mathrm{~mm}$.

According to the values of the gap between the electrodes of the spark plug, with the use of Bosch BEA 460 gas analyzer, the content of the following components of the exhaust gases $\mathrm{CO}$, $\mathrm{HC}, \mathrm{O}_{2}$ and $\mathrm{CO}_{2}$ is determined for two engine's crankshaft frequencies.
\end{abstract}




\section{Vasyl Brytkovskyi, Roman Kachmar, Olena Lanets}

Keywords: car, engine, gas fuel, power supply and ignition, spark plug, the gap between electrodes, crankshaft rotational frequency, exhaust gas toxicity, component content, carbon monoxide, hydrocarbons.

\section{Introduction}

The safety of environment and indicators of hazard influence of exhausted gases in the process of operation of vehicles are very important issues nowadays. As the gas fuel can provide more economy to the vehicle owners, the interest among the researches on the issue of supplying engines with gas fuels has been increased. In this case economic reasons, such as a reduction in the costs of the operation of the vehicle especially in Ukraine, where there is a big number of the cars with a high mileage, the operation of such car is obviously less expensive with gas fuel supply.

It is important to take in account all indicators caused by changing of the supply system by gas fuel assembly. Researches in this field are important for providing high efficiency and ecological indicators, which is an extremely important issue today.

Spark plugs are operating in the most extreme conditions. In a very short period of time microexplosions of a flammable mixture of fuel and air, high compressive pressure, and a high-temperature affect spark plugs. Spark plugs are intended to ignite a compressed mixture of air and gas in cylinders of the combustion engine. The efficiency of spark plugs is influenced by the value of the gap between the central and ground electrodes. It can vary for different operating conditions and it is influenced by the fuel used for the engine, the degree of compression of the working mixture, the type of ignition system and other factors. Even a small deviation of the parameters of the gap between electrodes of the spark plug can cause a malfunction in the work of the engine. This value directly affects spark creation and engine operation.

\section{Problem Statement}

Recently, the problem of increasing the environmental impact from emissions of mobile sources has sharply aggravated due to the increasing of the amount of vehicles imported into the country as transit, the technical condition of which does not meet not only the requirements of the European Union but also the requirements of the current legislation of Ukraine, in particular, the requirements of the toxicity of exhaust gases of engines of such cars. The current legislation of Ukraine on customs matters determines the procedure and conditions for the import of goods and vehicles of commercial purpose to the customs territory of Ukraine according to the customs regime "transit" [1]. At the same time, a large number of inhabitants of the country use legal gaps and import the car as if they were in transit, although they actually use it on a regular basis, and sometimes even as a taxi. According to [2], more than 1,751 million vehicles with foreign registration were imported into the customs territory of Ukraine in the mode of "temporary import" and "transit", of which - 1,313 million - was imported in the mode of "temporary import" by nonresidents. Residents of Ukraine imported more than 105.4 thousand cars in temporary admission. In the "transit mode", 332,900 vehicles were imported into Ukraine, of which more than 300,000 were imported by residents. Such vehicles are serviced situationally, periodically and on-demand only, in such vehicles the neutralizing exhaust gases system or the soot-capture system have been wrecked, and electronic engine control units are reprogrammed, and all petrol versions are reconstructed on cheaper gas fuels systems.

\section{Review of Modern Information Sources on the Subject of the Paper}

Investigations of the influence of the operating properties of car systems on the toxicity of exhaust gases of motor vehicles, including the transition to gaseous fuels, were carried out by a large number of scientists, in particular, Gutarevych, Yu.F. [4], Mateichyk V.P., [5] Korpach A.O., [6] Filipova G.A. [7], which investigated the influence of various parameters of engine systems and the influence of operating and temperature conditions of gas engine systems on the change of toxicity of exhaust gases by the individual components. At the same time, low attention was paid to the influence of the ignition system's regulation on the indicators of the toxicity of exhaust gases for modern types of engines, where even factory standards allow the change of gap in the spark plug in a large range [8]. Therefore, the task was to 


\section{Influence of the Ignition System Parameters on the Ecological Indicators of the Automobile ...}

determine the influence of the gap in the spark plug on the change of the toxicity indicators of the exhaust gases of the gasoline car engine with the use of gas motor fuels.

\section{Objectives and Problems of Research}

As previous joint exhaust gas toxicity tests of motor vehicles show [3], the main malfunctions that cause excessive toxicity are the power supply and ignition systems malfunctions, in particular, spark plug malfunction or inconsistencies of the gap between electrodes. Therefore, the task which was stated in research is to determine the influence on the environmental performance of exhaust gases of the vehicle engine transferred on gas fuel caused by the gap between the electrodes of the spark plug of petrol engines with gas fuel supply.

\section{Main Material Presentation}

A significant advantage of an automobile engine with the use of gas motor fuels is a significant reduction of harmful substances in the exhaust gases of an automobile engine with the use of gas motor fuel. Also, since the fuel is fed to the combustion engine in a gaseous state, in the absence of rinsing of the oil film from the cylinder's surface and reducing the wear of the cylinder-piston group, the gas does not affect the viscosity of the motor oil and its resource. In addition, the possibility of detonation due to the higher octane number of liquefied petroleum gas (103-109) is reduced and due to the practical absence of heavy admixtures in the gas, the life of the catalytic converter of the exhaust gases and the oxygen sensor is increased, the life of the spark plug is increased.

The choice of spark plugs for internal combustion engine (ICE) must be carried out subject to compliance with the law norms, namely the toxicity of exhaust gases, electromagnetic compatibility and, in the long term, $\mathrm{CO}_{2}$ emissions. Other parameters of the ICE, such as power and torque are not decisive but are essential for the owner of the car, therefore, additionally, the optimization of the ignition timing angles in all modes of operation of the ICE is held. In engines with an electronic control system this can only be done in the manufacturer conditions.

The composition of the exhaust gases depends primarily on the type of hydrocarbon fuel and, secondly, on the composition of the fuel-air mixture. The amount of emissions of $\mathrm{CO}$ and $\mathrm{CO}_{2}$ in carbon content in one or another fuel, that is in the hydrogen-carbon number, is the ratio of the number of hydrogen atoms to the number of carbon atoms in the molecule. The hydrogen-carbon number is about 2 for gasoline (consisting of several hydrocarbon compounds), for propane-butane it is 2.6, for methane it is 4. The relation of hydrogen to carbon monoxide in products of combustion for gasoline is from 0,45 to 0,5 , for propane-butane it is 0,615 , for methane it is 0,75 . That is, reducing of emissions of $\mathrm{CO}$ and $\mathrm{CO}_{2}$ during the transition from gasoline to propane-butane at the identical composition of fuel and air mixture will be from 11.5 to $16.5 \%$, and for methane, this decrease can range from 25 to $28 \%$. These percentages indicate that the amount of solid carbon sediments (soot) on the walls of the combustion chamber will be less on the same amount. Reducing the emissions of $\mathrm{CO}$ and $\mathrm{CO}_{2}$ more than these values can only be because of an incorrect comparison of ICE with gasoline and gas fuel.

In the light of the above, the choice of the assessment criterion for any of the elements of the ICE (including spark plugs), which affect its toxicity of the exhaust gases, must be carried out using the environmental hazard criterion.

The choice of the heat number for spark plugs depends on the ignition temperature of the fuel-air mixture. As the ignition and combustion temperatures of gasoline and propane-butane vapor are close in values, so, the heat number of the spark plugs for these types of fuels is approximately the same. For methane (natural gas), the ignition temperature is much higher and, accordingly, the heat number of the plugs should be different from the plugs for gasoline, that is, the plugs should be hotter. All this applies to two-fuel ICE without increasing the compression ratio when switching from gasoline to gas. In this case, the plugs should allow work on both types of fuel.

Detonation number of gas fuels is higher than of gasoline. For propane butane, the detonation number is about 105, and for natural gas (methane) it is about 120. Accordingly, with a greater degree of 


\section{Vasyl Brytkovskyi, Roman Kachmar, Olena Lanets}

compression of gas fuels kinds, we get a higher temperature of the mixture before ignition, that is, it will require less amount of energy to activate the chemical reaction of oxidation of fuel. In this case, for singlefuel gas ICE with a high compression ratio, the heat number of spark plugs when working on gas (propanebutane) and on gasoline can be approximately the same. For natural gas (methane) for single-fuel ICE with an increased compression degree up to $12.5 \ldots 15$ the heat number of spark plugs should be different from plugs purposed for gasoline because the heat of combustion of natural gas is higher than that of gasoline. The summarized amount of heat from the high compression and heat that is released when combusted methane will be higher than for a steam of gasoline and, accordingly, it will be necessary to select more cold plugs to exclude the probability of the ignition.

The purpose of the spark plug is to supply energy to the fuel-air mixture to ignite it. Ignition will occur if the energy supplied by the plug in the form of energy required for the ionization of the molecules in the discharge arc and the heat released in the spark gap will be higher than the summarized activation energy for the minimum volume of the mixture for starting of the chemical reaction. Practically from 3 to $10 \%$ of the energy stored in an ignition coil winding is spent on ignition. Another energy is spent on its dissipation under the short circuit through the spark discharge on the vehicle mass.

The difference in the spark plugs is in high efficiency of the spark's energy use for the ionization of the molecules and its transformation into thermal energy in the maximum volume of the mixture near the electrodes. Due to this, the initial temperature of the fuel-air mixture increases, on which the initial speed of combustion depends. In addition, the more is ionization of fuel molecules and oxidants near the spark plug electrodes, the higher the pressure level in the shock wave is, which is created by the spark, and the higher the speed of its displacement from the plug electrodes to the walls of the combustion chamber is. The shock wave leads to an increase in the temperature of the mixture in the flame. Since gasoline consists of heavier fractions of hydrocarbons, when it is ionized in a spark gap, a large number of moles of ionized carbon atoms, hydrogen and radicals $(\mathrm{CO}, \mathrm{CH}, \mathrm{OH}$, etc.) are formed. A larger number of moles increases the total pressure in a shock wave, because it consists of partial pressures of the constituent moles of atoms and radicals. And when methane decomposing on ionized atoms and radicals, we obtain a smaller number of moles $\mathrm{C}, \mathrm{H}$, and $\mathrm{CH}$. In this case, the total pressure in the shock wave is much lower than for gasoline. Therefore, increasing the initial temperature of the mixture due to the shock wave will be not significant.

The bigger the distance of the spark gap and the greater the number of spark arcs, so the more ions we obtain in the decomposition of the molecules and, the greater the amount of heat is exuded to heat a larger volume of fuel-air mixture to overcome the activation energy and the beginning of the chemical reaction of the oxidation process in the volume of spark gap. These factors also affect the overall efficiency of spark plugs. This can explain the differences in spark plugs, even for one type of hydrocarbon fuel (gasoline or gas).

The researches were carried out on a ZAZ Lanos 1.4 vehicle with the engine MeMZ 317. The engine MeMZ 317 is 8-valve, the working volume is 1.4 liters, the power system is a distributed injection. The car has outfit of gas equipment (propane-butane) of the $4^{\text {th }}$ generation Stag 200 GoFast with toroidal cylinder.

To determine the composition of the exhaust gases of the engine, equipment of the Training Center for Computer Diagnostics of Vehicles "Lviv Polytechnic - Bosch Academy" (Fig. 1) was used, in particular, the gas analyzer Bosch BEA 460, which is intended for gas analysis on cars with gasoline and gas engines for components such as $\mathrm{CO}, \mathrm{HC}, \mathrm{NO}, \mathrm{O}_{2}$ and $\mathrm{CO}_{2}$. The Bosch BEA 460 gas analyzer connects to the computer through the Bluetooth wireless interface, which allows providing substantial mobility.

The Champion RN9YC spark plugs were used for the research. According to the developed methodology of conducting researches, the preliminary change of the gap in the spark plugs from 0.6 to 1.4 $\mathrm{mm}$ with the step of $0.1 \mathrm{~mm}$ was made using a set of probes of different thickness.

Subsequently, using the gas analyzer Bosch BEA 460 in accordance with the requirements of DSTU 4277:2004 [9], measurements of the content of the main components of the exhaust gases $\mathrm{CO}, \mathrm{HC}, \mathrm{O}_{2}$ and $\mathrm{CO}_{2}$ were carried out during the work of heated to the operating temperature engine ZAZ Lanos 1.4 on the gas fuel. In the general case, the measurement was performed according to such an algorithm: 


\section{Influence of the Ignition System Parameters on the Ecological Indicators of the Automobile ...}

- move the shift lever to neutral, turn on the parking brake;

- carry out testing of gas analyzer leak, open the hood and connect the tachometer to the highvoltage conductor of the first cylinder, set the oil temperature sensor instead of the oil level indicator probe;

- immerse the sampler probe of the gas analyzer in the exhaust pipe of the car at a depth of at least $300 \mathrm{~mm}$ from the cut and start the engine;

- to set the minimum engine revolutions in accordance with the requirements of DSTU 4277:2004 and to measure the content of carbon monoxide and hydrocarbons after stabilizing the values of the gas analyzer;

- to set a higher rotational speed of the engine shaft after stabilizing the gas analyzer's shows, but not later than after 60 seconds, to carry out measurements of the content of carbon monoxide and hydrocarbons (Fig. 2) and to take the arithmetic average between the maximum and minimum gas consumption for the measurement interval, based on measurements.

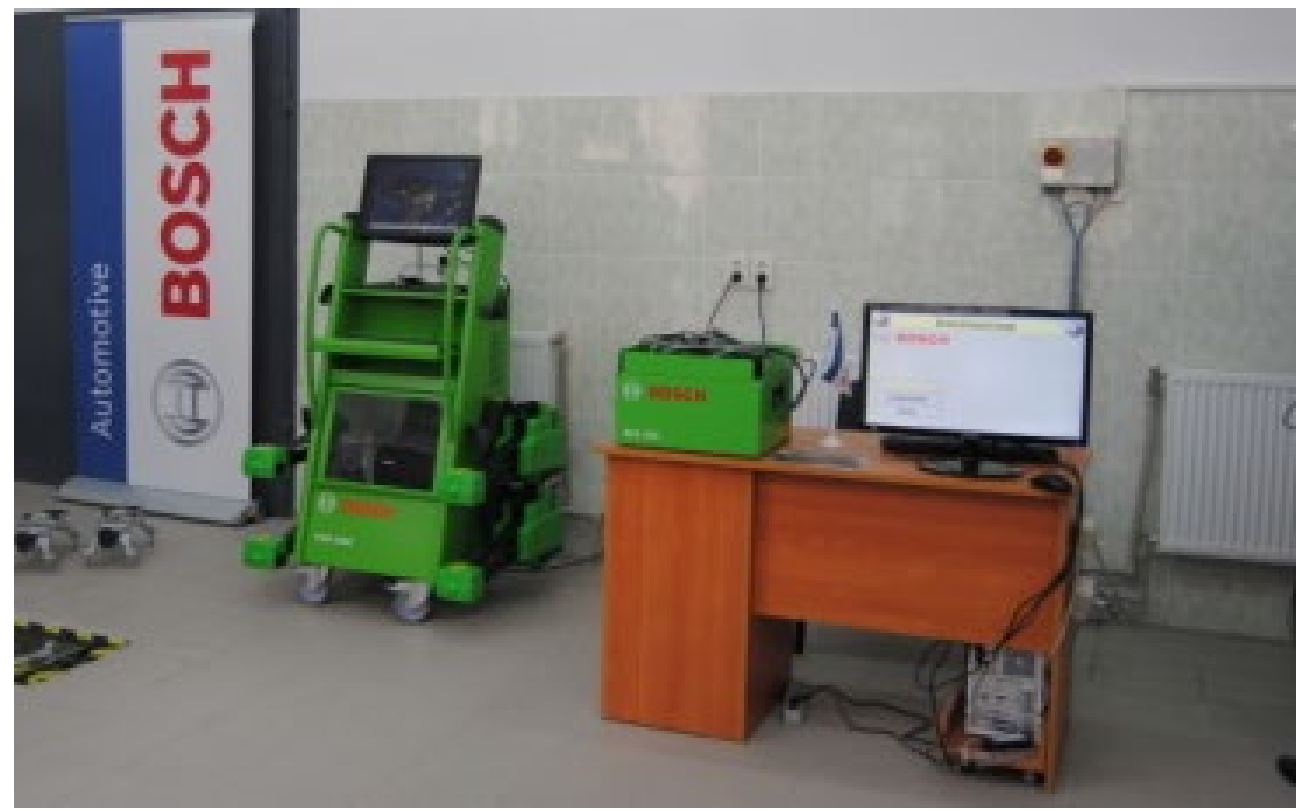

Fig. 1. Equipment of training center of computer diagnostics of vehicles laboratory "Lviv Polytechnic - Bosch Academy"

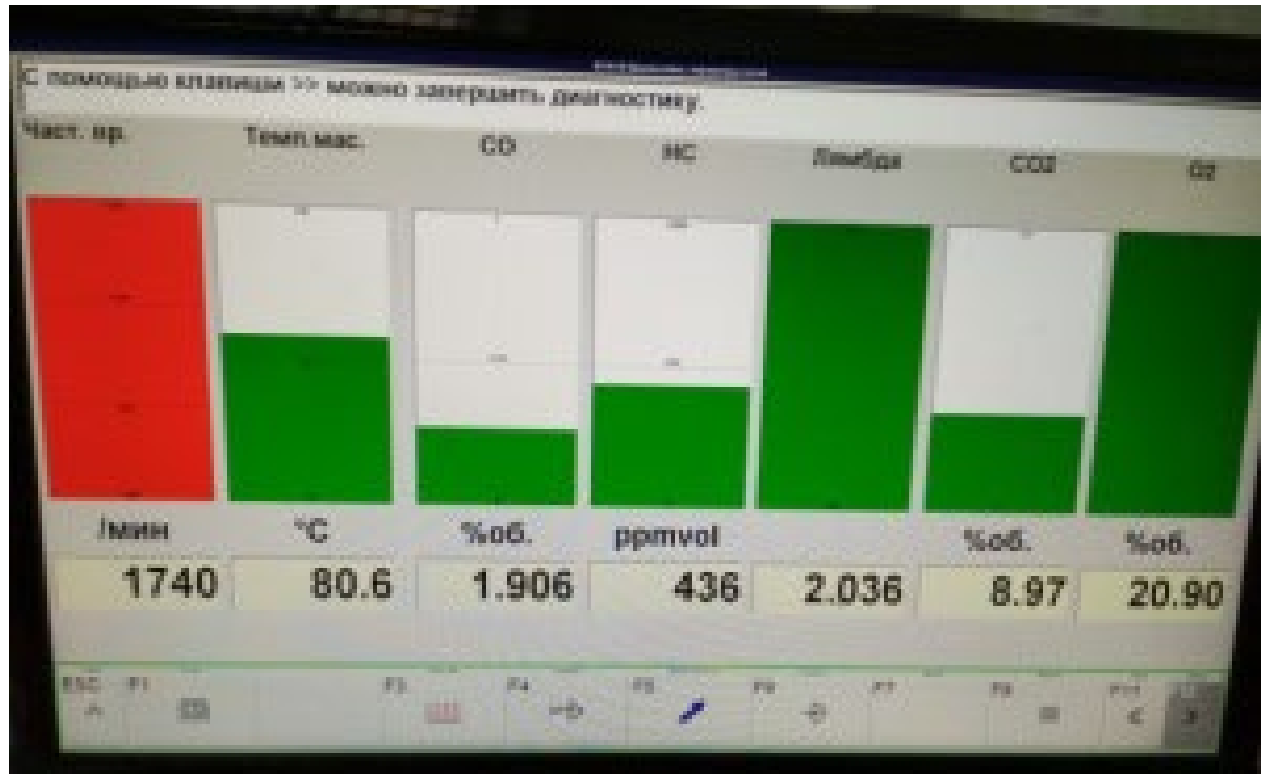

Fig. 2. Output of the measurement results on the computer screen 


\section{Vasyl Brytkovskyi, Roman Kachmar, Olena Lanets}

During the test, the vehicle uses gaseous fuels and lubricants as prescribed by the vehicle's operating regulations. The exhaust system of the car is fully equipped, and does not have mechanical holes and leaks in the joints.

According to the results of the research, the dependence of the change in the content of hydrocarbons in the exhaust gases of the gas engine on the value of the interelectrode gap of the spark plug for two crankshaft rotational frequencies (Fig. 3) was constructed. According to the results, an increase in hydrocarbon emissions at speed values of the crankshaft idling for small values of the interelectrode gap of the spark plug is obtained, in particular, for a gap value of $0.7 \mathrm{~mm}$, the release of hydrocarbons is 400 million $^{-1}$, while for a gap of $0.6 \mathrm{~mm}$ is 500 million $^{-1}$. The minimum value of hydrocarbon emissions is observed in the gap range of 1.0-1.3 mm for the rotational frequency of the idle speed of the gas engine's crankshaft. Almost the same minimum values are observed for an increased frequency of rotation - the minimum value is 86 million $^{-1}$ for a gap of $1.0 \mathrm{~mm}$ and reaches a value of 115 million $^{-1}$ up to a gap of $1.4 \mathrm{~mm}$.

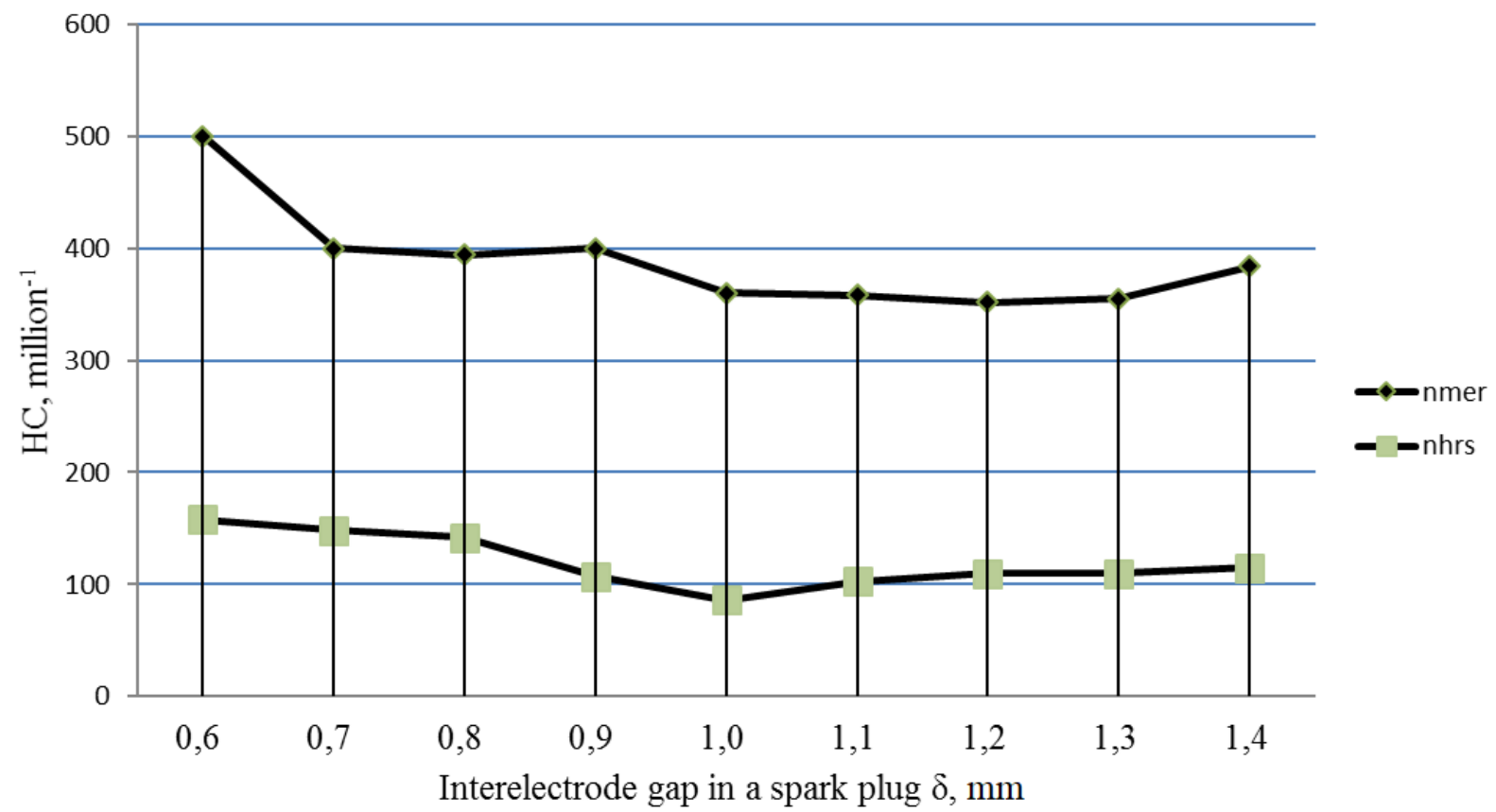

Fig. 3. Dependence of hydrocarbon content in the exhaust gases of the gas engine on the value of the interelectrode gap of the spark plug for two crankshaft rotational frequencies

Also, it was obtained the dependence of the change in the content of carbon monoxide in the exhaust gases of the gas engine on the value of the gap between electrodes of the spark plug for idling and the increased frequency of rotation of the crankshaft (Fig. 4). For the idle rotational frequency of the crankshaft, the highest value of CO content was observed at an interelectrode gap of $1.1 \mathrm{~mm}$ and exceeded 3 vol.\%. At the same time, it is clearly observed the minimum value of CO content is $1.3 \mathrm{vol} \% \mathrm{CO}$ at a gap of $0.7 \mathrm{~mm}$. For the increased crankshaft rotational frequency, the content of the carbon monoxide in exhaust gases remained practically unchanged throughout all the range of spark plugs interelectrode gap from 0.6 to $1.4 \mathrm{~mm}$ and acquired values are from 0.109 to $0.125 \mathrm{vol} \% \mathrm{CO}$.

Taking into account the previously received graphs, the change in the content of $\mathrm{CO}_{2}$ in the exhaust gases of the gas-fueled engine could be forecasted (Fig. 5).

When working on an idle speed of such engine, the change in gas content, at growth from the minimum to the maximum gap of a spark plug, is from 8.6 to 9.9 vol.\% It is known that a low level of $\mathrm{CO}_{2}$ indicates that the fuel mixture is enriched or poor, and the maximum values of $\mathrm{CO}_{2}$ content are observed when the composition of the mixture approaches the stoichiometric number [10]. Moreover, according to the passing of changes in the content of $\mathrm{CO}_{2}$, at the rotational frequency of the engine's crankshaft, which corresponds to idling, the maximum value of $\mathrm{CO}_{2}$ content is observed at a value of $0.6 \mathrm{~mm}$ of the 


\section{Influence of the Ignition System Parameters on the Ecological Indicators of the Automobile ...}

interelectrode gap of the spark plug and is 9.9 vol.\% $\mathrm{CO}_{2}$. At the same time, at an increased frequency of rotation, the maximum value of gas content is observed at a value of $1.4 \mathrm{~mm}$ of the interelectrode gap of the spark plug and is 9.6 vol. $\% \mathrm{CO}_{2}$.

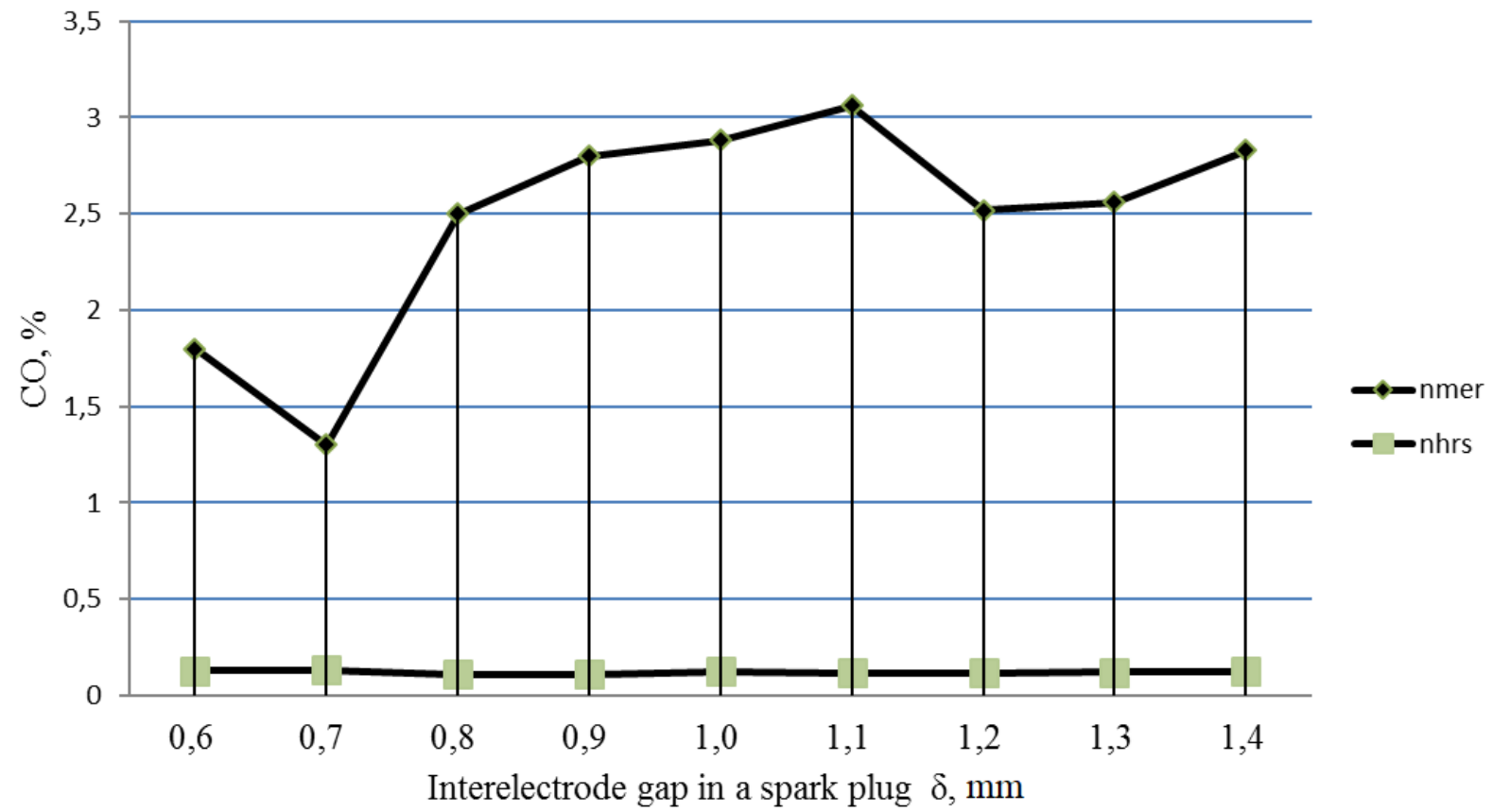

Fig. 4. Dependence of the carbon monoxide content in the exhaust gases of the gas engine on the value of the interelectrode gap of the spark plug for two crankshaft rotational frequencies

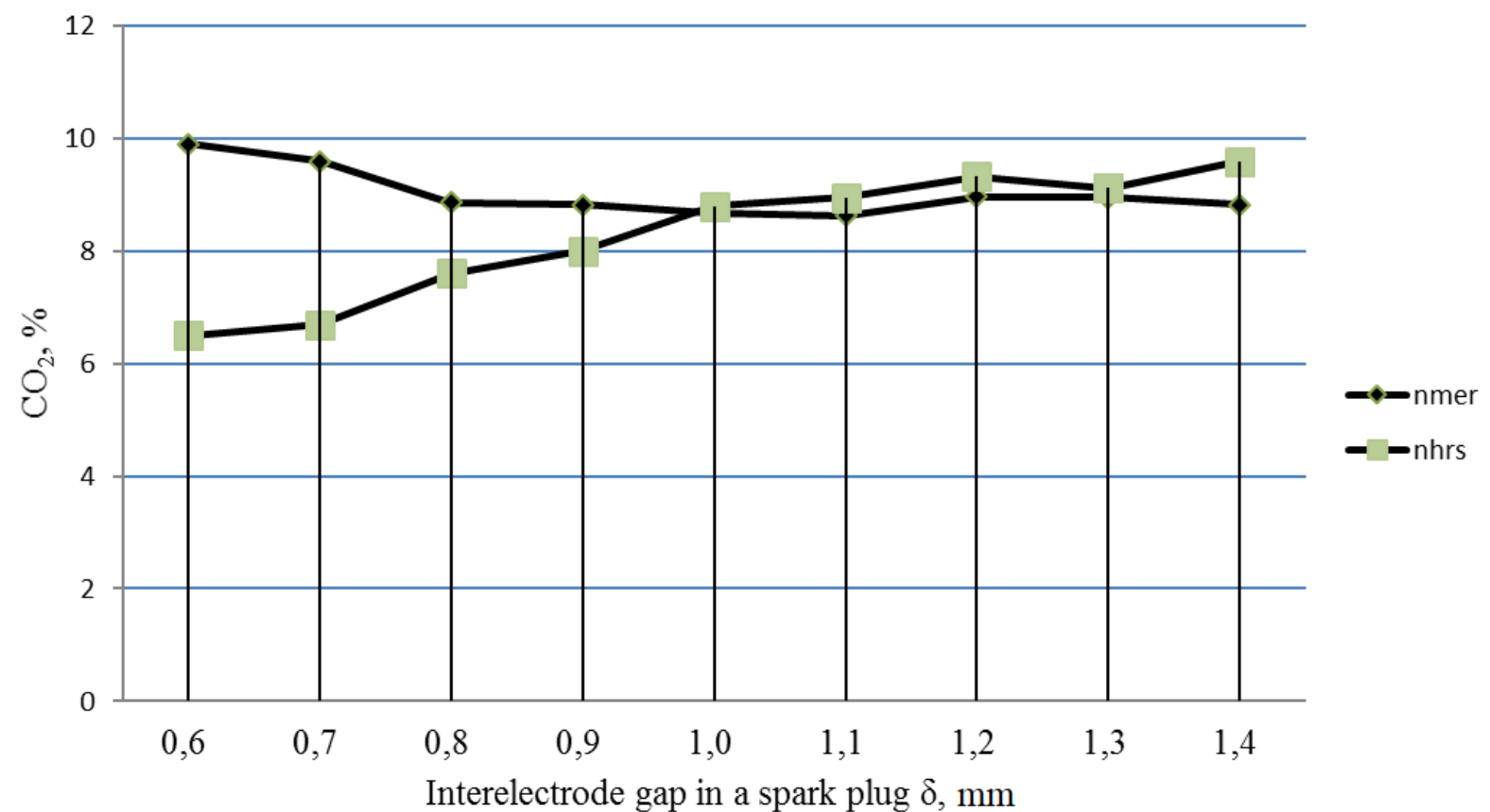

Fig. 5. Dependence of the content of $\mathrm{CO}_{2}$ in the exhaust gases of the gas engine on the value of the interelectrode gap of the spark plug for two crankshaft rotational frequencies

\section{Conclusions}

It is obvious that the interelectrode gap of the spark plug cannot be less than $0.7 \mathrm{~mm}$, as the quality of the gas-air mixture igniting process is sharply worsen, skips in the ignition of the fuel mixture are occurring, which leads to increase in emissions of hydrocarbon content in the exhaust gases, reduction of power and increase in fuel consumption. It is clearly visible the minimum values of hydrocarbon emissions 


\section{Vasyl Brytkovskyi, Roman Kachmar, Olena Lanets}

in the exhaust gases of the car engine when powered by gas at a spark plug gap of $1 \mathrm{~mm}$ on high rotational frequencies. Reduction of the carbon monoxide content at small gaps of the spark plug can be explained due to the appearance of ignition skips and uneven operation of the engine at idling speed, moreover, at higher crankshaft speeds the CO content does not depend on the interelectrode gap of the spark plug.

On the basis of the conducted analysis it can be contended that the interelectrode gap of the spark plug should be approximately $1 \mathrm{~mm}$. With such a gap during the combustion of liquefied petroleum gas in the ICE of MeMZ 317 there are optimal emissions of hydrocarbons $\mathrm{CH}, \mathrm{CO}$, and $\mathrm{CO}_{2}$ and, accordingly, they correspond to DSTU 4277:2004.

\section{References}

[1] Vvezennya transportnykh zasobiv u rezhymi tranzytu [Import of vehicles in transit mode]. Electronic resource. Log access mode: http://www.visnuk.com.ua/ua/pubs/id/6869.

[2] Skol'ko "yevroblyakh" v Ukraine i chto s nimi delat'? [How many "Euroblesses" are located in Ukraine and what to do with them?]. Electronic resource. Log access mode: https://ukranews.com/publication/2280-skolkoevroblyakh-v-ukrayne-y-chto-s-nymy-delat.

[3] Ye. Yu. Fornalchyk, and R. Ya. Kachmar, "Zalezhnist toksychnosti vidpratsovanykh haziv benzynovykh dvyhuniv vid rehuliuvan systemy zhyvlennia i zapaliuvannia" ["Dependence of toxicity of exhaust gases of gasoline engines from adjustments of the system of supply and ignition"], Visnyk Donetskoho natsionalnoho tekhnichnoho universytetu [Bulletin of Donetsk National Technical University], vol. 2, no. 9, pp. 33-36, 2009. [in Ukrainian].

[4] Yu. F. Gutarevich, S. V. Kariev, I. V. Manko, and V. V. Slavin, "Vplyv typu systemy zhyvlennia na ekolohichni pokaznyky benzynovoho dvyhuna" ["Effect of the type of power system on the environmental performance of the gasoline engine"], Visnyk Natsionalnoho transportnoho universytetu [Bulletin of National Transport University], vol. 24, no. 1, pp. 86-93, 2011. [in Ukrainian].

[5] V. P. Mateichyk, V. V. Yanovskyi, and O. V. Zakharchuk, "Perevirka adekvatnosti matematychnoi modeli ruhu kolisnoho traktora $\mathrm{z}$ hazovym dvyhunom u yizdovomu tsykli" ["Checking the adequacy of the mathematical model of the motion of the wheeled tractor with the gas engine during the driving cycle"], Naukovi Notatky [Scientific Notes], vol. 36, pp. 200-203, 2012. [in Ukrainian].

[6] A. O. Korpach, and O. M. Zakharchenko, "Vplyv kuta vyperedzhennia zapaliuvannia na pokaznyky dvyhuna za roboty na sumishevykh palyvakh" ["Influence of the ignition angle on engine performance for mixed fuels"], Problemy transportu [Transport problems], vol. 4, pp. 99-102, 2007. [in Ukrainian].

[7] H. A. Philipova, "Eksperymentalni doslidzhennia tiahovo-shvydkisnykh vlastyvostei i palyvnoi ekonomichnosti hazobalonnykh avtomobiliv" ["Experimental studies of traction-speed properties and fuel efficiency of gas cylinders vehicles"], Systemni metody keruvannia, tekhnolohiia ta orhanizatsiia vyrobnytstva, remontu $i$ ekspluatatsii avtomobiliv [System management techniques, technology and organization of production, repair and operation of cars], vol. 3, pp. 64-66, 1997. [in Ukrainian].

[8] K. P. Bykov, and T. A. Shlenchyk, Avtomobil AvtoZAZ-Daewoo Sens 1.3i, Lanos 1.4i. Ekspluatatsyia, obsluzhyvanie, remont [AvtoZAZ-Daewoo Sens 1.3i, Lanos 1.4i vehicle. Operation, maintenance, repair]. Chernihiv, Ukraine: Ranok Publ.,2010. [in Russian].

[9] Systema standartiv $u$ haluzi okhorony navkolyshnoho pryrodnoho seredovyshcha ta ratsionalnoho vykorystannia resursiv. Atmosfera. Normy $i$ metody vymiriuvannia vmistu oksydu vuhletsiu ta vuhlevodniv $u$ vidpratsovanykh hazakh avtomobiliv z dvyhunamy, shcho pratsiuiut na benzyni abo hazovomu palyvi [The system of standards in the field of environmental protection and rational use of resources. Atmosphere. Standards and methods for measuring the content of carbon monoxide and hydrocarbons in the exhaust gases of cars with engines operating on gasoline or gas fuels], DSTU 4277:2004. [in Ukrainian].

[10] O. A. Beshun, and O. A. Marus, "Osoblyvosti utvorennia shkidlyvykh komponentiv u vidpratsovanykh hazakh dvyhuniv liso-i silskohospodarskykh traktoriv" ["Peculiarities of formation of harmful components in exhaust gases of engines of forest and agricultural tractors"], Naukovyi visnyk Natsionalnoho universytetu bioresursiv i pryrodokorystuvannia Ukrainy. Seriia: Tekhnika ta enerhetyka APK [Scientific bulletin of the National University of Bioresources and Nature Management of Ukraine. Series: Technics and Power Engineering of Agroindustry complex], vol. 226, pp. 393-405, 2015. [in Ukrainian].

[11] M. P. Hrebniak, and R. A. Fedorchenko, "Peresuvni dzherela zabrudnennia atmosfernoho povitria industrialnoho mista u suchasnykh umovakh" ["Mobile sources of atmospheric air pollution in an industrial city in modern conditions"], Dovkillia ta zdorovia [Environment and health], vol. 4, pp. 26-29, 2015. [in Ukrainian]. 